\title{
ANTIBODY FORMATION IN MYELOMATOSIS
}

BY

\author{
J. MARKS \\ From the Public Health Laboratory, Cardiff
}

(RECEIVED FOR PUBLICATION SEPTEMBER 14, 1952)

In recent years several workers have submitted evidence suggesting that plasma cells are the site of antibody formation (e.g., Fagraeus, 1948). In the present work antibody production, as indicated by circulating levels of staphylococcal $\alpha$-antitoxin and antistreptolysin $\mathrm{O}$, has been studied in patients with myelomatosis, a disease characterized by disordered growth of plasma cells. In addition to cases of myelomatosis, patients with hyperglobulinaemia due to other causes were examined serologically, and both series were compared with a group of normal persons.

\section{Experimental Methods}

Serum levels of staphylococcal $\alpha$-antitoxin were estimated by methods described previously (Marks, 1951). A similar technique was used for estimating serum antistreptolysin $\mathrm{O}$, titration end-points being determined by haemolysis and not by its absence, as some workers prefer. In both instances antitoxin titrations were conducted at intervals of $20 \%$.

The sera from patients with hyperglobulinaemia due to causes other than myelomatosis were received from several different pathologists in response to an appeal, and were otherwise unselected.

\section{Results}

Table I records the distribution of serum levels of staphylococcal $\alpha$-antitoxin and antistreptolysin $\mathrm{O}$ in the normal persons examined. These values are provided as standards with which the remaining results may be compared. Two hundred and twenty-four subjects were examined, half in each series.

In Table II are shown the levels of serum globulin, albumin, and antitoxin in 17 cases of myelomatosis and in 17 patients with hyperglobulinaemia due to other causes. In eight of the myelomatosis patients one or both of the antitoxin levels was extremely low, and in five others moderately low. The highest antitoxin levels were found in cases 15 , 16 , and 17 , in association with normal levels of serum albumin and globulin, and in cases 16 and
TABLE I

SERUM LEVELS OF STAPHYLOCOCCAL a-ANTITOXIN AND ANTISTREPTOLYSIN O IN NORMAL PERSONS

No. of Individuals with Given Serum Levels (units $\mathrm{ml}$.)

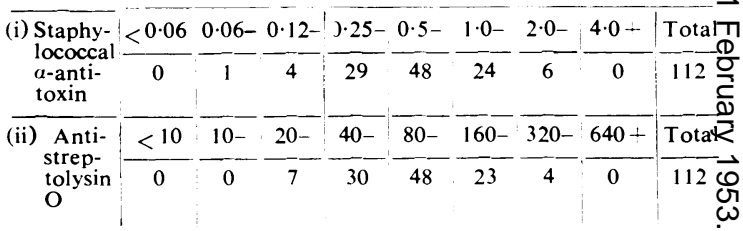

TABLE II

SERUM PROTEIN AND ANTITOXIN LEVELS IN MYELOMA ํํำ TOSIS AND UNSELECTED CASES OF HYPERGLOBULIN AEMIA DUE TO OTHER CAUSES

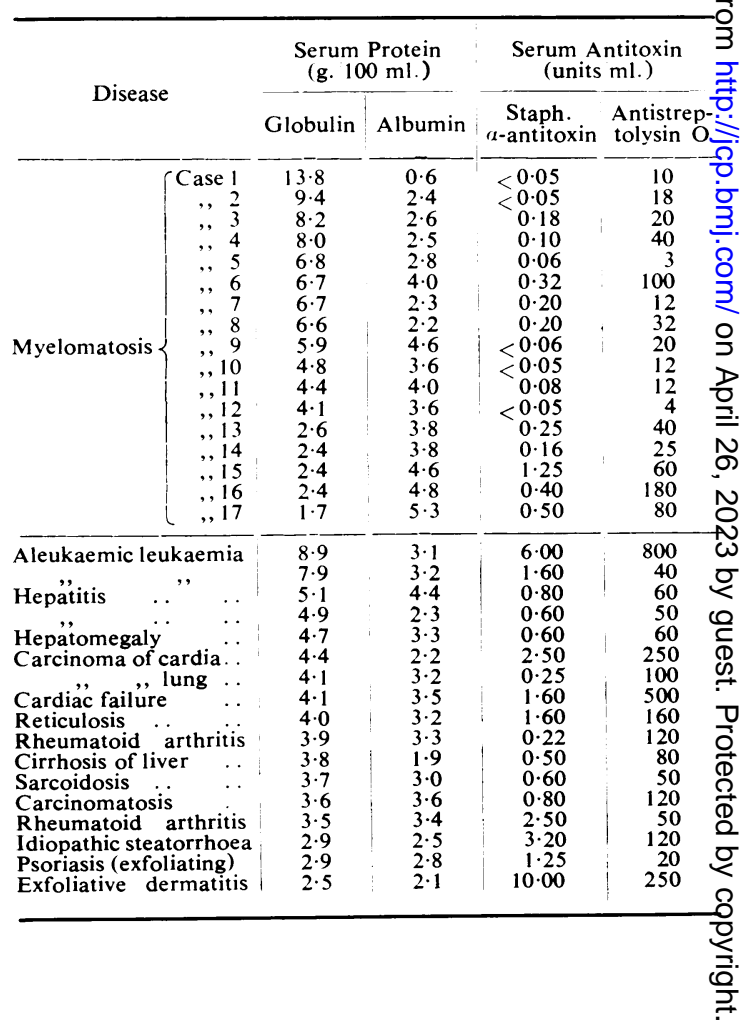


17 with normal electrophoretic patterns. In case 13 the serum protein values were not grossly abnormal, but electrophoretic examination some months previously had shown a deficiency of $\gamma$-globulin and an excess of $\alpha$-globulin. From the length of history in this case, which has been reported elsewhere, the disease appeared to possess a very low degree of malignancy (Campbell, 1951). Case 17 resembled case 13 in the slow progress and limited extent of the disease ; diagnosis was also made by biopsy, marrow films showing a relatively slight excess of plasma cells. Shortly before $x$-ray therapy the serum levels of albumin were 4.0 and globulin $3.0 \mathrm{~g} . / 100 \mathrm{ml}$.; the protein and antitoxin values recorded in Table II were determined 15 months later. No atypical features were reported in the remaining cases.

Among the hyperglobulinaemic patients without myelomatosis there were no subnormal levels of antistreptolysin $O$. Their levels of staphylococcal $\alpha$-antitoxin were, in general, above the mean normal value, and differed considerably from those of the myelomatosis patients.

\section{Discussion}

A wide range of antitoxin levels was found in the normal persons studied. Nevertheless, in most of the myelomatosis patients studied, antitoxin levels could be considered subnormal. All but one of the remaining levels fell in the lower half of the normal range. There was some evidence in the myelomatosis cases of a negative correlation between the degree of hyperglobulinaemia and antibody levels.

It is probable that antibodies are produced by the cells responsible for the manufacture of undifferentiated serum globulin. The deranged growth of plasma cells in myelomatosis appears to be frequently associated with depressed antibody formation as well as with the presence of abnormal serum globulins demonstrable by chemical, physical, or immunological methods. This association suggests that plasma cells are concerned in the manufacture of serum globulin and antibodies. Antibody production is normal or increased in conditions characterized by an excess of qualitatively normal serum globulin, in which plasma cell function is apparently stimulated and not disordered.

It is possible that the diagnosis of myelomatosis with hyperglobulinaemia may be helped by serological examination. Very low serum antitoxin levels $(<0.1$ unit of staphylococcal $\alpha$-antitoxin or $<20$ units of antistreptolysin $O$ per $\mathrm{ml}$.) support a diagnosis of myelomatosis, and medium or high levels $(>0.5$ unit of $\alpha$-antitoxin or $>120$ units of antistreptolysin $\mathrm{O}$ per $\mathrm{ml}$.) are evidence against it. In the first case of aleukaemic leukaemia in Table II the high antibody levels cast doubt on an original diagnosis of myelomatosis which was corrected on re-examination of histological material.

Plasma cell proliferation has been shown to occur in a number of conditions other than myelomatosis, including chronic infections (Bayrd, 1948 ; Fadem and McBirnie, 1950). In chronic infections, at least, an excess of plasma cells in the bone marrow may be accompanied by hyperglobulinaemia, and in such circumstances serological examination might assist diagnosis.

\section{Summary}

Serum levels of staphylococcal $\alpha$-antitoxin and antistreptolysin $O$ were found to be low in the majority of $17^{*}$ cases of myelomatosis examined. Myelomatosis patients with hyperglobulinaemia appear most likely to exhibit depressed antibody formation. Hyperglobulinaemia due to other diseases was found to be associated with normal or high antitoxin levels.

I am indebted to many colleagues for their generous provision of sera and clinical notes, to Mr. J. W. Keyser for the electrophoretic analysis of two sera, and to Professor J. Gough and Dr. Scott Thomson for their advice.

\section{REFERENCES}

Bayrd, E. D. (1948). Blood, 3, 987.

Campbell, R. T. (1951). Proc. roy. Soc. Med. 44, 408.

Fadem, R. S., and McBirnie, J. E. (1950). Blood, 5, 191.

Fagraeus, A. (1948). Acta med. scand., Suppl. 204.

Marks, J. (1951). J. Hyg., Camb., 49, 52.

* Four new cases of myelomatosis have been examined with similar serological findings. 